NATIONAL LABORATORY

\title{
Vision Document for the AMP Nuclear Fuel Performance Code
}

\author{
February 2011
}

\section{Prepared by}

Kevin Clarno, Bibby Philip, William Cochran, Jay Billings, and Gary Dilts Oak Ridge National Laboratory

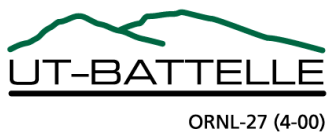




\title{
DOCUMENT AVAILABILITY
}

Reports produced after January 1, 1996, are generally available free via the U.S. Department of Energy (DOE) Information Bridge.

Web site http://www.osti.gov/bridge

Reports produced before January 1, 1996, may be purchased by members of the public from the following source.

\author{
National Technical Information Service \\ 5285 Port Royal Road \\ Springfield, VA 22161 \\ Telephone 703-605-6000 (1-800-553-6847) \\ TDD 703-487-4639 \\ Fax 703-605-6900 \\ E-mail info@ntis.gov \\ Web site http://www.ntis.gov/support/ordernowabout.htm
}

Reports are available to DOE employees, DOE contractors, Energy Technology Data Exchange (ETDE) representatives, and International Nuclear Information System (INIS) representatives from the following source.

Office of Scientific and Technical Information

P.O. Box 62

Oak Ridge, TN 37831

Telephone 865-576-8401

Fax 865-576-5728

E-mail reports@osti.gov

Web site http://www.osti.gov/contact.html

This report was prepared as an account of work sponsored by an agency of the United States Government. Neither the United States Government nor any agency thereof, nor any of their employees, makes any warranty, express or implied, or assumes any legal liability or responsibility for the accuracy, completeness, or usefulness of any information, apparatus, product, or process disclosed, or represents that its use would not infringe privately owned rights. Reference herein to any specific commercial product, process, or service by trade name, trademark, manufacturer, or otherwise, does not necessarily constitute or imply its endorsement, recommendation, or favoring by the United States Government or any agency thereof. The views and opinions of authors expressed herein do not necessarily state or reflect those of the United States Government or any agency thereof. 


\title{
VISION DOCUMENT FOR THE AMP NUCLEAR FUEL PERFORMANCE CODE
}

\author{
Kevin Clarno \\ Bibby Philip \\ William Cochran \\ Jay Billings \\ Gary Dilts
}

Date Published: February 2011

Prepared by

OAK RIDGE NATIONAL LABORATORY

Oak Ridge, Tennessee 37831-6283

managed by

UT-BATTELLE, LLC

for the

U.S. DEPARTMENT OF ENERGY

under contract DE-AC05-00OR22725 


\title{
VISION DOCUMENT FOR THE AMP NUCLEAR FUEL PERFORMANCE CODE
}

\author{
Kevin T. Clarno, Bobby Philip, William K. Cochran, Jay J. Billings, Gary Dilts
}

February 28, 2011

\section{INTRODUCTION}

The Advanced Modeling and Simulation Office (AMSO) with the United States (U.S.) Department of Energy (DOE) Office of Nuclear Energy (DOE/NE) oversees the Nuclear Energy Advanced Modeling and Simulation (NEAMS) program and the Consortium for Advanced LWR Simulation (CASL), an Energy Innovation Hub. NEAMS is a program to develop advanced modeling and simulation capabilities for state-of-the-art and next generation nuclear energy applications and is composed of four Integrated Performance and Safety Code (IPSC) elements and four Cross-Cutting elements.

The vision for the Fuels IPSC is to deliver an assessed (verified and validated) simulation capability to the fuel design and research community that is capable of predicting the behavior of nuclear fuel, cladding, and structural materials during nominal operation and anticipated operational transients that are beyond the well validated empirical basis that has historically required many integral experiments and operational experience for even moderate changes to fuel designs. Within the Fuels IPSC, the AMP(Advanced MultiPhysics) Nuclear Fuel Performance code (AMP) is targeted for the design and evaluation of Integral Effects Experiments, prediction and evaluation of in-reactor operation, and sensitivity/uncertainty evaluations that will be used to guide the development of lower-length-scale (LLS) research [1]. There is also substantial work in progress to understand the lower-length-scale physics (grain-scale and below) of nuclear fuel, cladding, and structural materials within the Fuels IPSC, as well as the Fundamental Methods and Models (FMM) Cross-Cutting program element.

\section{POSITIONING}

\subsection{Problem Statement}

The lack of a modern engineering-scale nuclear fuel performance and safety code affects:

- the nuclear fuel research community,

- because there is no vehicle for efficiently evaluating the performance and safety benefits of novel designs and materials,

- the nuclear fuel industry,

- by constraining their ability to understand, and correct, the primary phenomena that lead to fuel failures, which has a significant financial impact,

- the lower-length-scale (LLS) simulation researchers,

- because there is no vehicle for efficiently evaluating the affects of their innovations on the integral performance and safety of the fuel, and

- the LLS research program managers, 
- because there is no consistent means, for a wide variety of fuel/reactor configurations, of evaluating the sensitivity of integral fuel performance to individual fundamental (separate) effects, which is needed to effectively utilize limited resources.

A successful solution would be the development of an assessed (verified and validated), easy-to-use, multi-dimensional, parallel, extensible fuel performance and safety code, at the continuum- and (limited) grain- scales, that is general enough to model a tremendous variety of fuel/reactor configurations with a simple mechanism for incorporating additional material models and a comprehensive approach to sensitivity analysis that incorporates all forms of uncertainties.

\subsection{Product Position Statement}

The AMP Nuclear Fuel Performance code is clearly described as unique with the position statement in Table 1.

Table 1: Position Statement

\begin{tabular}{|l|l|}
\hline $\begin{array}{l}\text { The AMP Nuclear Fuel } \\
\text { Performance code }\end{array}$ & $\begin{array}{l}\text { will be an assessed (verified and validated), easy-to-use, multi-dimensional, } \\
\text { parallel, extensible fuel performance and safety code, at the continuum- and } \\
\text { (limited) grain-scales, }\end{array}$ \\
\hline That is & $\begin{array}{l}\text { general enough to model a tremendous variety of fuel/reactor configurations } \\
\text { with a simple mechanism for incorporating additional material models and a } \\
\text { comprehensive approach to sensitivity analysis that incorporates all forms of } \\
\text { uncertainties }\end{array}$ \\
\hline Which is unlike & legacy fuel performance codes, such as FRAPCON, FALCON, and LIFE, \\
\hline Because AMP & $\begin{array}{l}\text { will be independent of any specific reactor/fuel type, will model three- } \\
\text { dimensional physics with substantially less engineering-scale simplifications, } \\
\text { will be capable of leveraging high-performance computing hardware, and will } \\
\text { incorporate extensive optimization, uncertainty quantification, and sensitivity } \\
\text { analysis tools. }\end{array}$ \\
\hline and also unlike & $\begin{array}{l}\text { research-focused fuel performance codes } \\
\text { the nuclear industry, will be easy-to-use by traditional fuel designers on desktop } \\
\text { to leadership-class computational platforms, and will account for all of the } \\
\text { physics that occurs within the fuel, even if only as simplified, phenomenological } \\
\text { models. }\end{array}$ \\
\hline Because AMP
\end{tabular}

\section{STAKEHOLDER DESCRIPTIONS}

There are three general forms of stakeholders that will be discussed:

1. the current, external stakeholders (Section 3.1, Table 2),

2. the internal stakeholders (Section 3.2, Table 3), and

3. the potential external stakeholders (Section 3.3, Table 4).

\subsection{External Stakeholder Summary}

The (current) external stakeholders for the AMP Nuclear Fuel Performance code are shown in Table 2. 
Table 2: External Stakeholders

\begin{tabular}{|c|c|c|}
\hline Name & Description & Responsibilities \\
\hline $\begin{array}{l}\text { NEAMS Leader- } \\
\text { ship }\end{array}$ & see Introduction. & $\begin{array}{l}\text { Agent by which funding is pro- } \\
\text { vided; customers of visualization } \\
\text { for AMSO program development } \\
\text { purposes; providers of high-level re- } \\
\text { quirements through interactions with } \\
\text { other DOE/NE programs. }\end{array}$ \\
\hline $\begin{array}{l}\text { NEAMS Fuels } \\
\text { IPSC program } \\
\text { manager (Steve } \\
\text { Hayes) }\end{array}$ & $\begin{array}{l}\text { Direct-report manager } \\
\text { charged with delivering } \\
\text { an integrated fuel per- } \\
\text { formance capability that } \\
\text { spans the LLS physics } \\
\text { and the AMP Nuclear } \\
\text { Fuel Performance code. }\end{array}$ & $\begin{array}{l}\text { Technical lead of the integrated fuel } \\
\text { performance capability; agent by } \\
\text { which funding is provided; customer } \\
\text { of visualization for Fuels IPSC pro- } \\
\text { gram development purposes; provider } \\
\text { of requirements for integrated fuel } \\
\text { performance capability. Note also } \\
\text { that the NEAMS Fuels IPSC program } \\
\text { manager is also a Fuel Performance } \\
\text { Expert and Primary Stakeholder (see } \\
\text { Section 3.2). }\end{array}$ \\
\hline $\begin{array}{l}\text { NEAMS Fuels } \\
\text { IPSC LLS physics } \\
\text { researchers }\end{array}$ & $\begin{array}{l}\text { Developers of both in- } \\
\text { tegrated and individual } \\
\text { atomistic and meso-scale } \\
\text { simulation tools, includ- } \\
\text { ing the MOOSE/Bison/- } \\
\text { Marmot code (MBM). }\end{array}$ & $\begin{array}{l}\text { Customers of AMP because they serve } \\
\text { as a vehicle to demonstrate the sig- } \\
\text { nificance of their model/algorithm } \\
\text { development work; customer of the } \\
\text { AMP sensitivity analyses, which can } \\
\text { guide the further development of mod- } \\
\text { els/algorithms; providers of software } \\
\text { and algorithms (for multi-scale mod- } \\
\text { eling) that may be coupled with, or } \\
\text { embedded in, AMP. }\end{array}$ \\
\hline CASL & $\begin{array}{l}\text { Integrated nominal op- } \\
\text { eration and transient } \\
\text { reactor/fuel code suite } \\
\text { for Light-Water Reactor } \\
\text { applications, with a near- } \\
\text { term focus on CRUD } \\
\text { prediction, Grid-to-Rod- } \\
\text { Fretting, and Pellet-Clad } \\
\text { Interaction. }\end{array}$ & $\begin{array}{l}\text { Customer of AMP that would in- } \\
\text { corporate it in a larger code suite; } \\
\text { customers of AMP because it may } \\
\text { serve as a vehicle to demonstrate the } \\
\text { significance of their LLS model/algo- } \\
\text { rithm development work; customer of } \\
\text { the AMP sensitivity analyses to guide } \\
\text { the further development of model- } \\
\text { s/algorithms; providers of software } \\
\text { and algorithms (for multi-scale mod- } \\
\text { eling) that may be coupled with, or } \\
\text { embedded in, AMP. }\end{array}$ \\
\hline $\begin{array}{l}\text { Fuel Cycle R \& D } \\
\text { TIO }\end{array}$ & $\begin{array}{l}\text { Technical lead for Fuel } \\
\text { Cycle research, Kemal } \\
\text { Pasamehmetoglu, and } \\
\text { supporting staff, includ- } \\
\text { ing Cetin Unal. }\end{array}$ & $\begin{array}{l}\text { Indirect sponsor and program man- } \\
\text { ager of the principal DOE/NE fuel } \\
\text { research customers; establishes the } \\
\text { long-term requirements and evaluates } \\
\text { performance with respect to a metric } \\
\text { of "usefulness to experimenters." }\end{array}$ \\
\hline $\begin{array}{l}\text { NEAMS Reactors } \\
\text { IPSC element }\end{array}$ & $\begin{array}{l}\text { A program element that } \\
\text { incorporates neutronics, } \\
\text { thermal-fluid dynamics, } \\
\text { and structural mechanics } \\
\text { for reactor system and } \\
\text { core modeling. }\end{array}$ & $\begin{array}{l}\text { Customer of AMP for integration } \\
\text { within their framework; potential } \\
\text { provider of requirements for multi- } \\
\text { physics coupling and communication. }\end{array}$ \\
\hline
\end{tabular}




\begin{tabular}{|c|c|c|}
\hline $\begin{array}{l}\text { NEAMS Capabil- } \\
\text { ity Transfer (CT) } \\
\text { Cross-Cutting } \\
\text { element }\end{array}$ & $\begin{array}{l}\text { A program element that } \\
\text { is focused on technology } \\
\text { transfer. }\end{array}$ & $\begin{array}{l}\text { Interfaces with industry and campaign } \\
\text { customers on behalf of the NEAMS } \\
\text { program to elicit requirements. Po- } \\
\text { tentially providing other services, such } \\
\text { as training courses and release/dis- } \\
\text { tribution/compilation assistance to } \\
\text { users. }\end{array}$ \\
\hline $\begin{array}{l}\text { NEAMS Enabling } \\
\text { Computational } \\
\text { Technologies } \\
\text { (ECT) Cross- } \\
\text { Cutting element }\end{array}$ & $\begin{array}{l}\text { A program element that } \\
\text { is focused on funda- } \\
\text { mental computational } \\
\text { technologies, including } \\
\text { assistance with foun- } \\
\text { dational computational } \\
\text { tools, software devel- } \\
\text { opment process, and } \\
\text { software quality assur- } \\
\text { ance. }\end{array}$ & $\begin{array}{l}\text { Providers of assistance and tools that } \\
\text { AMP will leverage; customers of the } \\
\text { AMP computational technology re- } \\
\text { quirements; customer because AMP } \\
\text { may serve as a vehicle to demonstrate } \\
\text { the significance of this cross-cutting } \\
\text { activity. }\end{array}$ \\
\hline $\begin{array}{l}\text { NEAMS Verifica- } \\
\text { tion, Validation } \\
\text { and Uncertainty } \\
\text { Quantification } \\
\text { (VU) Cross- } \\
\text { Cutting element }\end{array}$ & $\begin{array}{l}\text { A program element that } \\
\text { provides independent } \\
\text { verification, validation, } \\
\text { uncertainty quantifica- } \\
\text { tion, sensitivity analysis, } \\
\text { and data assimilation } \\
\text { (VVUQSADA) expertise } \\
\text { and tools. }\end{array}$ & $\begin{array}{l}\text { Providers of assistance and tools } \\
\text { related to VVUQSADA that AMP } \\
\text { will leverage; AMP customers pri- } \\
\text { marily focused on demonstrating } \\
\text { VVUQSADA (for non-intrusive UQ) } \\
\text { applied to nuclear energy problems; } \\
\text { provider of requirements for intrusive } \\
\text { VVUQSADA. }\end{array}$ \\
\hline $\begin{array}{l}\text { NEAMS Funda- } \\
\text { mental Models and } \\
\text { Methods (FMM) } \\
\text { Cross-Cutting } \\
\text { element }\end{array}$ & $\begin{array}{l}\text { A program element that } \\
\text { provides fundamental } \\
\text { materials, models, and } \\
\text { methods that are applica- } \\
\text { ble to multiple IPSCs or } \\
\text { are still in the fundamen- } \\
\text { tal research stage. }\end{array}$ & $\begin{array}{l}\text { Customer of requirements; potential } \\
\text { provider of material models and algo- } \\
\text { rithms for upscaling of LLS physics. }\end{array}$ \\
\hline $\begin{array}{l}\text { ORNL Manage- } \\
\text { ment }\end{array}$ & $\begin{array}{l}\text { The management to } \\
\text { which the AMP develop- } \\
\text { ers at ORNL report, both } \\
\text { directly and indirectly. }\end{array}$ & $\begin{array}{l}\text { Customers of visualization for nuclear, } \\
\text { computing, and materials program } \\
\text { development; invested in the techni- } \\
\text { cal success of the project, strategic } \\
\text { direction of the software, and financial } \\
\text { status of the project. }\end{array}$ \\
\hline $\begin{array}{l}\text { LANL Manage- } \\
\text { ment }\end{array}$ & $\begin{array}{l}\text { The management to } \\
\text { which the AMP develop- } \\
\text { ers at LANL report, both } \\
\text { directly and indirectly. }\end{array}$ & $\begin{array}{l}\text { Customers of visualization for nuclear, } \\
\text { computing, and materials program } \\
\text { development; invested in the techni- } \\
\text { cal success of the project, strategic } \\
\text { direction of the software, and financial } \\
\text { status of the project.. }\end{array}$ \\
\hline INL Management & $\begin{array}{l}\text { The management to } \\
\text { which the Fuels ISPC } \\
\text { developers and Fuel Per- } \\
\text { formance Experts at INL } \\
\text { report, both directly and } \\
\text { indirectly. }\end{array}$ & $\begin{array}{l}\text { Customers of visualization for nuclear, } \\
\text { computing, and materials program } \\
\text { development; invested in the techni- } \\
\text { cal success of the project, strategic } \\
\text { direction of the software, and financial } \\
\text { status of the project.. }\end{array}$ \\
\hline
\end{tabular}




\subsection{Internal Stakeholder Summary}

The internal stakeholders for the AMP Nuclear Fuel Performance code are shown in Table 3 and described in more detail in Reference [2].

Table 3: Internal Stakeholders

\begin{tabular}{|l|l|l|}
\hline Role & Name & Responsibilities \\
\hline $\begin{array}{l}\text { Primary } \\
\text { Stakeholder }\end{array}$ & Steve Hayes & $\begin{array}{l}\text { Primary interface to current, external stakeholders; lead } \\
\text { for gathering requirements from the current, external } \\
\text { stakeholders and acceptance testing based on the current, } \\
\text { external stakeholder requirements. }\end{array}$ \\
\hline $\begin{array}{l}\text { Project } \\
\text { Manager } \\
\text { interface to external stakeholders; lead for (internal and } \\
\text { external) communication, including gathering require- } \\
\text { ments from internal stakeholders; lead for strategic plan- } \\
\text { ning, including gathering requirements from potential, } \\
\text { external stakeholders. }\end{array}$ \\
\hline $\begin{array}{l}\text { Architecture } \\
\text { Lead }\end{array}$ & Bobby Philip & $\begin{array}{l}\text { Manage the comprehensive (external and internal) set of } \\
\text { software requirements and acceptance testing based on } \\
\text { the internal and potential, external requirements; lead the } \\
\text { iterative software design process. }\end{array}$ \\
\hline $\begin{array}{l}\text { Process } \\
\text { Lead }\end{array}$ & Bill Cochran & $\begin{array}{l}\text { Lead for defining and overseeing the process to be used } \\
\text { in software development and quality assurance; a direct } \\
\text { interface to the NEAMS VU and ECT program elements } \\
\text { at the technical level. }\end{array}$ \\
\hline $\begin{array}{l}\text { Fuel Per- } \\
\text { formance } \\
\text { Experts }\end{array}$ & $\begin{array}{l}\text { Test the code during development; guide it to become } \\
\text { more accurate; apply it to mission-critical applications. }\end{array}$ \\
\hline $\begin{array}{l}\text { Software } \\
\text { Developers }\end{array}$ & $\begin{array}{l}\text { Scientific } \\
\text { Researchers }\end{array}$ & $\begin{array}{l}\text { Define and document the development plan; implement } \\
\text { and document the software. }\end{array}$ \\
\hline $\begin{array}{l}\text { Pest- } \\
\text { Doctoral } \\
\text { Researchers } \\
\text { Researchers and evaluate the performance (accuracy, effi- } \\
\text { ciency, scalability) of the software and publish the results; } \\
\text { software developers at national laboratories are also scien- } \\
\text { tific researchers. }\end{array}$ \\
$\begin{array}{l}\text { As software developers and scientific researchers, it is } \\
\text { imperative that they also get established in a field and } \\
\text { acquire a job, which requires journal publications. }\end{array}$ \\
$\begin{array}{l}\text { As software developers and scientific researchers, it is im- } \\
\text { perative that they also complete their dissertation and } \\
\text { publish. }\end{array}$ \\
\hline
\end{tabular}

\subsection{Potential Stakeholder Summary}

The potential stakeholders for the AMP Nuclear Fuel Performance code are shown in Table 4.

Table 4: Potential Stakeholders

\begin{tabular}{|l|l|l|}
\hline Name & Description & Responsibilities \\
\hline $\begin{array}{l}\text { Nuclear Fuel } \\
\text { Industry }\end{array}$ & GE, Westinghouse, & $\begin{array}{l}\text { Must have a very high quality assurance and val- } \\
\text { Areva }\end{array}$ \\
$\begin{array}{l}\text { idation plan for LWRs; also must allow for imple- } \\
\text { mentation of proprietary models }\end{array}$ \\
\hline
\end{tabular}




\begin{tabular}{|l|l|l|}
\hline $\begin{array}{l}\text { Nuclear } \\
\text { Regulatory } \\
\text { Commission } \\
\text { (NRC) }\end{array}$ & $\begin{array}{l}\text { Regulating body } \\
\text { of the nuclear fuel } \\
\text { industry. }\end{array}$ & $\begin{array}{l}\text { A strategic decision will be required regarding } \\
\text { the decision to support either the industry or the } \\
\text { regulator, but it is not likely possible to support } \\
\text { both. }\end{array}$ \\
\hline $\begin{array}{l}\text { Naval Reac- } \\
\text { tors (NR) }\end{array}$ & $\begin{array}{l}\text { DOE national } \\
\text { laboratories that } \\
\text { support the US } \\
\text { Nuclear Navy. }\end{array}$ & $\begin{array}{l}\text { Potential customers, but would move AMP Nuclear } \\
\text { Fuel Performance code towards a classified tool. }\end{array}$ \\
\hline
\end{tabular}

\subsection{User Environment}

The targeted users for the AMP Nuclear Fuel Performance code are described in detail in Reference [3].

\section{PRODUCT OVERVIEW}

\subsection{Product Perspective}

The AMP Nuclear Fuel Performance code is part of the Fuels IPSC, as noted in the introduction (Section 1 and described in more detail in Reference [1], which includes a related software development effort called MOOSE/Bison/Marmot code (MBM). The relationship between the two projects is described in detail in Reference [1], which includes an overview of the relationship as reproduced in Table 5 of this document.

Table 5: Overview of the relationships of AMP and MBM

\begin{tabular}{|l|l|l|l|}
\hline & MBM & AMP & MBM +AMP \\
\hline User Community & $\begin{array}{l}\text { SE experimenters, } \\
\text { AMP developers }\end{array}$ & $\begin{array}{l}\text { IE experimenters, } \\
\text { reactor IPSC de- } \\
\text { velopers }\end{array}$ & $\begin{array}{l}\text { novel fuel design- } \\
\text { ers, novel reactor } \\
\text { designers }\end{array}$ \\
\hline Benefit & $\begin{array}{l}\text { Insight into funda- } \\
\text { mental mechanisms }\end{array}$ & $\begin{array}{l}\text { Evaluation of the } \\
\text { performance of } \\
\text { prototypic fuel, } \\
\text { cladding, and/or } \\
\text { structures }\end{array}$ & $\begin{array}{l}\text { Prediction of the } \\
\text { performance of nu- } \\
\text { clear fuel with no } \\
\text { empirical database }\end{array}$ \\
\hline $\begin{array}{l}\text { Relevance of codes } \\
\text { to one another }\end{array}$ & $\begin{array}{l}\text { Calibrated, vali- } \\
\text { dated correlations } \\
\text { and quantified un- } \\
\text { certainties for use } \\
\text { in AMP }\end{array}$ & $\begin{array}{l}\text { Sensitivity of } \\
\text { fundamental mech- } \\
\text { anisms to guide } \\
\text { MBM development }\end{array}$ & $\begin{array}{l}\text { Resolution of } \\
\text { nonlinear bi- } \\
\text { directional scale } \\
\text { cascades }\end{array}$ \\
\hline $\begin{array}{l}\text { Role of experi- } \\
\text { ment and design } \\
\text { community }\end{array}$ & $\begin{array}{l}\text { Provide SE data } \\
\text { for validation and } \\
\text { calibration }\end{array}$ & $\begin{array}{l}\text { Provide IE data } \\
\text { for validation and } \\
\text { insight into missing } \\
\text { physics and models }\end{array}$ & $\begin{array}{l}\text { Defining novel fuel } \\
\text { forms and support- } \\
\text { ing experiments }\end{array}$ \\
\hline $\begin{array}{l}\text { Source of input } \\
\text { data }\end{array}$ & $\begin{array}{l}\text { DFT and atomistic } \\
\text { simulations }\end{array}$ & $\begin{array}{l}\text { Calibrated, vali- } \\
\text { dated correlations } \\
\text { from mesoscale } \\
\text { simulations }\end{array}$ & $\begin{array}{l}\text { DFT and atomistic } \\
\text { simulations }\end{array}$ \\
\hline $\begin{array}{l}\text { Source of valida- } \\
\text { tion data }\end{array}$ & $\begin{array}{l}\text { Separate Effects } \\
\text { Experiments (SE) }\end{array}$ & $\begin{array}{l}\text { Integral Effects } \\
\text { experiments (IE) }\end{array}$ & n/a \\
\hline
\end{tabular}




\subsection{Assumptions and Dependencies}

The following dependencies and assumptions are included in the requirements for the development of the AMP Nuclear Fuel Performance code. It is assumed that the AMP Nuclear Fuel Performance code will get:

- a user interface from NEAMS ECT (NiCE) that will be very nice.

- support from NEAMS CT in user support, training courses, and distribution.

- support from NEAMS ECT in build/configure/test and software quality assurance.

- support from NEAMS VU in independent verification.

- algorithms, data, and maybe code, for grain-scale modeling from the other developers in the Fuels IPSC, including the MOOSE/Bison/Marmot code .

- expert user feedback from friendly users within the Fuels IPSC before any code is openly released.

- consistent funding at, or above, the present level.

If the assumptions prove false, additional scope will be added to this project.

\subsection{Needs and Features}

The requirements for the AMP Nuclear Fuel Performance code are described in detail in Reference [3]. 


\section{References}

[1] K. Clarno, R. Martineau, G. Dilts, and S. Hayes, NeAmS Integration of the AMP and MBM Fuel Performance Codes for Multi-Scale Fuel Performance Modeling and Simulation, Technical report, Idaho National Laboratory, 2010, Unpublished document delivered to DOE Office of Nuclear Energy as a Milestone reportd.

[2] K. Clarno and B. Philip, Roles and Responsibilities for the AMP Nuclear Fuel Performance Code, Technical report, Oak Ridge National Laboratory, 2010, Within the source documentation of the AMP Nuclear Fuel Performance code.

[3] B. Philip, W. Cochran, K. Clarno, and J. Billings, Requirements Document for the AMP Nuclear Fuel Performance Code, Technical report, Oak Ridge National Laboratory, 2010, Within the source documentation of the AMP Nuclear Fuel Performance code. 